Politik Indonesia: Indonesian Political Science Review 2 (2) (2017) 141-158
Politik Indonesia
Indonesian Political Science Review
http://journal.unnes.ac.id/nju/index.php/JPI
Indonesia

\title{
Model Pengembangan Ekowisata dalam Upaya Pemberdayaan Masyarakat Lokal
}

\author{
Muhammad Ama Ridlwan ${ }^{1 凶}$, Slamet Muchsin ${ }^{2}$, Hayat $^{3}$ \\ ${ }^{1}$ Universitas Islam Malang, Indonesia
}

\begin{tabular}{|c|c|}
\hline Info Artikel & Abstrak \\
\hline $\begin{array}{l}\text { Sejarah Artikel: } \\
\text { Diterima 5 Juni } 2017 \\
\text { Disetujui } 18 \text { Juni } 2017 \\
\text { Dipublikasi } 15 \text { Juli } 2017\end{array}$ & $\begin{array}{l}\text { Dewasa ini para wisatawan mulai menggemari tempat wisata yang tidak hanya } \\
\text { sekedar menyajikan keindahan alamnya saja tetapi lebih kepada interaksi } \\
\text { masyarakat, oleh karena itu mulai berkembang jenis wisata minat khusus yaitu desa } \\
\text { wisata. Seperti halnya Kampung Wisata Ekologis (KWE) Puspa Jagad di Desa }\end{array}$ \\
\hline $\begin{array}{l}\text { Keywords: } \\
\text { Ecotourism; Tourism } \\
\text { Development; } \text { Model } \\
\text { Community Based Tourism } \\
\text { (CBT); KWE Puspa } \\
\text { Universe }\end{array}$ & $\begin{array}{l}\text { edukasi atau biasa disebut ekowisata kepada wisatawan. Dengan adanya } \\
\text { pengembangan pariwisata ini masyarakat akan diberdayakan melalui kegiatan } \\
\text { pariwisata. Penelitian ini bertujuan untuk menerapkan model Community Based } \\
\text { Tourism (CBT) dalam pengembangan pariwisata yang ada di KWE Puspa Jagad } \\
\text { serta peran pemerintah dan masyarakat dalam upaya pengembangan KWE Puspa } \\
\text { Jagad dan untuk mengetahui apa saja faktor pendukung dan penghambat yang } \\
\text { dimiliki KWE Puspa Jagad. Metode penelitian ini menggunakan jenis penelitian } \\
\text { deskriptif dengan pendekatan kualitatif dengan mengumpulkan data berupa data } \\
\text { primer dan sekunder. Teknik analisis yang digunakan dalam penelitian ini yaitu } \\
\text { observasi, wawancara, dan dokumentasi. Dari hasil penelitian menunjukkan bahwa } \\
\text { KWE Puspa Jagad dalam pengembangan ekowisata sudah menerapkan prinsip- } \\
\text { prinsip Community Based Tourism (CBT) yang dapat dilihat dari kegiatan-kegiatan } \\
\text { yang diadakan oleh pengelola KWE Puspa Jagad, peran pemerintah dan peran aktif } \\
\text { masyarakat dalam pengembangan KWE Puspa Jagad menjadikan KWE Puspa Jagad } \\
\text { semakin maju dan berkembang. Kemudian faktor pendorong dan penghambat yang } \\
\text { dimiliki KWE Puspa Jagad dalam merumuskan strategi terbaik dalam } \\
\text { pengembangan wisata. }\end{array}$ \\
\hline
\end{tabular}

\begin{abstract}
$\overline{\text { Today the tourists began to idolize attractions that not only serves its natural beauty }}$ alone but rather to intetaksi society, therefore, began to develop the type of special interest is a tourist village. Just as Ecological Tourism Village (KWE) Puspa Cement Universe in the village of Blitar District of Gandusati offers nature tourism and ecotourism education or commonly referred to tourists. With the development of this tourism community will be empowered through tourism activities. This study aims to apply the model of Community Based Tourism (CBT) in the development of tourism in the KWE Puspa Universe and the role of government and society in the development of KWE Puspa universe and to know what are the factors supporting and owned KWE Puspa Universe. This research method using descriptive research with a qualitative approach to collect data in the form of primary and secondary data. The analysis technique used in this study are observation, interviews, and documentation. The results showed that KWE Puspa Universe in the development of ecotourism has been applying the principles of Community Based Tourism (CBT), which can be seen from the activities that were held by KWE Puspa Universe, the role of government and active role in community development makes KWE KWE Puspa Puspa Universe Universe and growing. Then the factors driving and inhibiting owned KWE Puspa Universe in formulating the best strategies in the development of tourism.
\end{abstract}

(C) 2017 Universitas Negeri Semarang

\footnotetext{
Alamat korespondensi:

Program Studi Ilmu Administrasi Publik, Fakultas Ilmu Administrasi, Universitas Islam Malang
}

J1. Mayjen Haryono 193 Malang, 65144. E-mail: arye.beng89@ gmail.com 


\section{Pendahuluan}

Pariwisata merupakan salah satu bidang industri yang bergerak dalam bidang pelayanan dan jasa yang menjadi salah satu andalan bangsa Indonesia dalam mendongkrak devisa negara. Perkembangan pariwisata di Indonesia yang sangat besar dan beragam untuk dapat dikembangkan menjadi destinasi pariwisata yang menarik dan menjadi tujuan utama wisata dunia. Saati ini, para wisatawan lebih menyukai wisata alam yang dikombinasi dengan peran serta masyarakat dalam kebudayaan dan sosial kemasyarakatannya. Interaksi sosial dalam dunia wisata menjadi kebutuhan yang harus dipenuhi sebagai bagian dari pengembangan dunia wisata.

Oleh karena itu, dibutuhkan alternatif wisata di tengah gemuruhnya tempat wisata yaitu desa wisata. Salah satu daerah yang berupaya mengembangkan pariwisata dengan memanfaatkan potensi lokal adalah Kabupaten Blitar. Kabupaten Blitar merupakan salah satu dari 38 Kabupaten yang berada di Provinsi Jawa Timur. Blitar memiliki total luas wilayah sebesar $1.588,70$ $\mathrm{km}$. Walaupun dengan luas yang relatif sempit ini, Blitar memiliki potensi besar untuk dikembangkan, terutama bidang kepariwisataan, baik berupa kepariwisataan yang menyajikan keindahan alam, sosial, budaya, dan sejarah.

Berdasarkan pada data yang diperoleh dari situs resmi Dinas Pemuda Olahraga Kebudayaan dan Pariwisata Kabupaten Blitar,
Kampung Wisata Ekologis (KWE) di Desa Semen termasuk dalam daftar objek wisata yang dikembangkan sebagai kawasan wisata alam dan edukasi atau biasa disebut dengan ekowisata. Kawasan Kampung Wisata Ekologis (KWE) di Desa Semen ini berada di bawah pengelolaan paguyuban Puspa Jagad, sehingga dinamakan Puspa Jagad dan berbatasan langsung dengan empat desa tetangga. Sebelah utara Desa Tulungrejo, sebelah selatan Desa Slumbung, sebelah barat Desa Soso, sebelah timur Desa Tegalasri. Menurut Nugroho (2011), “ekowisata merupakan suatu perjalanan wisata yang bertanggung jawab pada kelestarian alam, budaya, serta memuat unsur-unsur edukasi”.

Di samping itu, ekowisata juga melibatkan masyarakat lokal dalam pengelolaannya sehingga dapat memberikan manfaat ekonomi kepada masyarakat ataupun pemerintah setempat. Sesuai dengan Peraturan Menteri Dalam Negeri Nomor 33 Tahun 2009 tentang Pedoman Pengembangan Ekowisata di Daerah yang menyebutkan bahwa "pengembangan ekowisata wajib memberdayakan masyarakat setempat" yang dalam hal ini sesuai dengan prinsip ekowisata yaitu peran aktif masyarakat sekitar dalam kegiatan perencanaan, pemanfaatan, dan pengendalian ekowisata dengan menghormati nilai-nilai sosial-budaya dan keagamaan masyarakat di sekitar kawasan wisata. Dengan adanya pengembangan ekowisata ini masyarakat diberdayakan melalui kegiatan pariwisata. 
Upaya pengembangan KWE Puspa Jagad dengan tujuan pemberdayaan masyarakat melalui kegiatan pembudidayaan anggrek alam di rumah-rumah warga, di bawah tanggung jawab paguyuban Puspa Jagad. Adapun jenis anggrek yang dibudidayakan di sini adalah jenis anggrek alam, seperti Spangisus, Dindrobium, Alba, Ekor Tupai, Vando Tree Colour, dan sebagainya. Selain itu, guna melayani permintaan dalam hal penginapan sebagian masyarakat menjadikan rumahnya sebagai homestay, mengingat di kawasan KWE Puspa Jagad ini belum terdapat hotel atau villa. Di bidang kesenian terdapat paguyuban Turonggo Sakti yang fokus pada kesenian jaranan atau kuda lumping. Ada juga kesenian langen beksan, campursari, dan beberapa upacara adat. Namun sangat disayangkan hanya segelintir masyarakat yang ikut berperan aktif dalam kegiatan kepariwisataan. Selain itu rendahnya antusiasme masyarakat sekitar menjadikan KWE Puspa Jagad menjadi kurang berkembang walaupun dengan keanekaragaman potensi yang dimiliki. Hal ini dikarenakan potensi desa belum terolah dengan sepenuhnya di samping keterbatasan kualitas sumber daya manusia.

Keberhasilan dalam pengembangan pariwisata ditandai dengan peningkatan kunjungan wisatawan di suatu destinasi wisata, sesuai data yang diperoleh dari pengelola Kampung Wisata Ekologis (KWE) Puspa Jagad terhitung dari tahun 2011 yaitu berjumlah 80 kunjungan wisata, 2012 mengalami peningkatan 1.490 kunjungan wisata yakni sebesar 1.570 kunjungan wisata, kemudian tahun 2013 mengalami penurunan hingga 830 kunjungan wisata menjadi 740 kunjungan wisata, kemudian tahun 2014 mengalami kenaikan lagi sebesar 873 kunjungan wisata yakni sebesar 1.613 kunjungan wisata, kemudian pada tahun 2015 mengalami kenaikan kunjungan wisata dari tahun sebelumnya yakni sebesar 2.327 kunjungan wisata yakni sebesar 3.940 kunjungan wisata, kemudian di tahun 2016 mengalami penurunan hingga 2.190 kunjungan wisata yakni sebesar 1.750 kunjungan wisata. Penurunan jumlah wisata ini secara langsung berpengaruh terhadap pendapatan masyarakat di sekitar objek wisata. Masyarakat yang menggantungkan hidup dari keberadaan objek wisata tersebut. Terancam gulung tikar karena pendapatan mereka turun drastis.

Penurunan kunjungan wisata di Kampung Wisata Ekologis (KWE) Puspa Jagad erat kaitannya dengan belum memadainya sarana prasarana di kawasan wisata Kampung Wisata Ekologis (KWE) Puspa Jagad seperti minimnya akses wisata, terbengkalainya insfrastruktur wisata, minimnya atraksi wisata, minimnya kesadaran masyarakat dalam mengembangkan wisata dan permasalahan lainnya yang berhubungan dengan pariwisata. Sehingga sebagian besar masyarakat di Kabupaten Blitar atau wisatawan luar daerah lebih memilih untuk mengalihkan tujuan wisatanya pada objek 
wisata daerah lain, daripada berwisata di objek wisata Kampung Wisata Ekologis (KWE) Puspa Jagad.

Perkembangan Kampung Wisata Ekologis (KWE) Puspa Jagad tidak langsung menjadi kawasan wisata, melainkan mengalami perkembangan yang cukup lama. Pada tahun 2011 kawasan Kampung Wisata Ekologis (KWE) Puspa Jagad menjadi destinasi wisata sejak dilakukannya riset oleh Vena Melinda, artis ibukota sekaligus menjabat sebagai anggota DPR dan berada di Komisi X, yaitu membidangi Pendidikan, Kebudayaan, Ekonomi Kreatif, Pariwisata, Pemuda, dan Olahraga di Jawa Timur. Beliau mengajukan Kampung Wisata Ekologis (KWE) Puspa Jagad untuk mengikuti Program Nasional Pemberdayaan Masyarakat Mandiri (PNPM Mandiri) Pariwisata dalam rangka membangun kesadaran masyarakat dan penguatan kelembagaan dalam hal potensi pariwisata yang dimiliki daerah masingmasing, sehingga masyarakat dapat menjadi perilaku yang handal dalam hal kepariwisataan di Indonesia (sumber: arsip pengelola Kampung Wisata Ekologis (KWE) Puspa Jagad). Sejak saat itu keberadaan KWE Puspa Jagad mulai dikenal oleh banyak orang luar daerah Kabupaten Blitar.

Dari penjelasan di atas penulis menarik rumusan masalah yaitu: Bagaimana peran baik pemerintah maupun masyarakat dalam pengembangan Kampung Wisata Ekologis (KWE) Puspa Jagad di Desa Semen?, Bagaimana penerapan model
Community Based Tourism (CBT) dalam pengembangan Kampung Wisata Ekologis (KWE) Puspa Jagad di Desa Semen dalam upaya pemberdayaan masyarakat lokal?, Apa saja faktor pendorong dan penghambat dalam pengembangan KWE Puspa Jagad di Desa Semen dalam upaya pemberdayaan masyarakat lokal?.

\section{Metode Penelitian}

Sesuai dengan permasalahan di atas penelitian ini menggunakan jenis penelitian deskriptif dengan pendekatan kualitatif. Pendekatan ini dipilih karena dalam pendekatan ini tidak hanya berambisi mengumpulkan data dari segi kualitas tetapi juga ingin memperoleh pemahaman yang lebih mendalam dibalik fenomena yang berhasil direkam. Berupa untuk memberikan gambaran secara luas atau uraian atas suatu keadaan atau fenomena sosial pendidikan secara jelas tanpa ada perlakuan terhadap objek yang diteliti dan yang terjadi.

Moleoeng (2011: 6) penelitian kualitatif adalah penelitian yang bermaksud untuk memahami fenomena tentang apa yang dialami oleh subjek penelitian misalnya perilaku persepsi, motivasi, tindakan, dan lain-lain. Secara holistik dan dengan cara deskriptif dalam bentuk kata-kata dan bahasa, pada suatu konteks khusus yang alamiah dan dengan memanfaatkan berbagai metode alamiah.

Sedangkan menurut Nazir (2005: 43) metode deskriptif adalah suatu metode dalam 
penelitian status kelompok manusia, suatu objek, suatu set kondisi, suatu sistem pemikiran, ataupun suatu kelas peristiwa pada masa sekarang. Selain itu, penelitian deskriptif juga terbatas pada usaha mengungkapkan suatu masalah, keadaan atau peristiwa sebagaimana adanya, sehingga bersifat sekedar untuk mengungkap fakta dan memberikan gambaran secara objektif tentang keadaan sebenarnya dari objek yang diteliti.

Adapun lokasi penelitian adalah tempat atau letak di mana penelitian ini akan dilaksanakan, untuk memperoleh data atau informasi yang diperlukan yang berkaitan dengan permasalahan yang akan diteliti. Lokasi penelitian adalah di Kabupaten Blitar, dengan situs penelitian di Desa Semen Kecamatan Gandusari Kabupaten Blitar. Adapun penelitian terhadap lokasi penelitian ini didasarkan pada pertimbangan bahwa keberadaan Kampung Wisata di Kabupaten Blitar yang bertemakan alam masih sangat sedikit, akan tetapi Kampung Wisata Alam dan Ekologis Puspa Jagad ini mampu bersaing dengan kampung wisata alam di kota-kota lain. Hal ini dibuktikan dari eksistensinya Kampung Wisata Ekologis Puspa Jagad sejak berdirinya pada tahun 2007 sampai dengan sekarang.

Penelitian menggunakan data primer dan sekunder yang didapat dengan cara wawancara, observasi dan dokumentasi di lokasi penelitian, yaitu Kampung Wisata Ekologis (KWE) Puspa Jagad di Desa Semen Kecamatan Gandusari Kabupaten Blitar.
Teknik analisis yang diapakai dalam penelitian ini adalah teknik analisis data yang dikembangkan oleh Mathew B. Miles dan Michael Huberman (1994). Model analisis data tersebut ini memiliki tiga alur yang terjadi secara bersamaan, yaitu: Reduksi Data, dimaksudkan sebagai proses pemilihan, pemusatan perhatian pada penyederhanaan, pengabstrakan dan transformasi data kasar yang muncul dari catatan tertulis di lapangan.

Penyajian Data, dimaksudkan sebagai sekumpulan informasi tersusun yang memberikan kemungkinan adanya penarikan kesimpulan dan pengambilan tindakan baik penyajian data dalam bentuk tabel maupun naratif yang menggabungkan informasi tersusun ke dalam bentuk yang padu. Hal ini dimaksudkan agar memudahkan bagi peneliti untuk melihat gambaran secara keseluruhan dan bagian-bagian tertentu dari penelitian. Penarikan Kesimpulan atau Verifikasi, merupakan menarik sebuah kesimpulan dari apa yang sudah diteliti.

Penelitian ini secara umum menganalisis peran Pemerintah Desa Semen dan peran masyarakat di kawasan Kampung Wisata Ekologis (KWE) Puspa Jagad dalam upaya pengembangan ekowisata. Sesuai dengan Peraturan Menteri Dalam Negeri Nomor 33 Tahun 2009 tentang Pedoman Pengembangan Ekowisata di Daerah Pasal 1 poin 6 yang menyebutkan bahwa "pelaku ekowisata adalah pemerintah, pemerintah daerah, dunia usaha, dan masyarakat yang bergerak di bidang wisata". Spillane (1991: 
133) menyebutkan bahwa Peran pemerintah dalam pengembangan pariwisata adalah sebagai penyedia infrastruktur, memperluas berbagai bentuk fasilitas, kegiatan koordinasi antara aparatur pemerintah dengan pihak swasta pengaturan dan promosi, sedangkan peran masyarakat menurut Suwantoro (2014: 85) menjelaskan peran masyarakat dapat dilakukan secara aktif dan pasif. Peran serta aktif dilaksanakan secara langsung, baik secara perseorangan maupun secara bersamasama, yang secara sadar ikut membantu program pemerintah dengan inisiatif dan kreasi mau melibatkan diri dalam kegiatan pengusahaan pariwisata atau melalui pembinaan rasa ikut memiliki di kalangan masyarakat. Peran serta pasif adalah timbulnya kesadaran masyarakat untuk tidak melakukan kegiatan-kegiatan yang dapat mengganggu atau merusak lingkungan alam di sekitar tempat wisata. Keikutsertaan masyarakat sekitar kawasan objek wisata dapat berbentuk usaha dagang atau pelayanan jasa, baik di dalam maupun di luar kawasan objek wisata. Jika kedua stakeholder tersebut dapat berjalan maksimal maka usaha wisata yang dilakukan oleh KWE Puspa Jagad dapat berjalan maksimal dan berkelanjutan.

Dari hasil analisis tersebut kemudian peneliti dapat merekomendasikan model Community Based Tourism (CBT) yang merupakan strategi perencanaan pengembangan kepariwisataan yang berorientasi pada pemberdayaan masyarakat setempat sebagai subjek pembangunan.
Sunaryo (2013: 140) dalam upaya pemberdayaan masyarakat dapat dilakukan melalui 3 prinsip pokok yaitu: 1) Mengikutsertakan anggota masyarakat dalam pengambilan keputusan; 2) Adanya kepastian masyarakat lokal menerima manfaat dari kegiatan kepariwisataan; 3) Pendidikan kepariwisataan bagi masyarakat lokal. Ketiga prinsip tersebut kemudian diterapkan pada pengembangan KWE Puspa Jagad di Desa Semen dalam upaya pmberdayaan masyarakat.

Adanya faktor pendorong dan penghambat yang dimiliki KWE Puspa Jagad kemudian digunakan sebagai strategi dalam pengembangan KWE Puspa Jagad dalam upaya pemberdayaan masyarakat di Desa Semen.

\section{Temuan dan Diskusi}

\section{Peran Pemerintah dan Masyarakat}

Keberhasilan suatu destinasi wisata tidak lepas dari peran pemerintah, pemerintah sangat perperan penting dalam penyedia insfrastruktur pariwisata. Sesuai dengan Peraturan Menteri Dalam Negeri Nomor 33 Tahun 2009 tentang Pedoman Pengembangan Ekowisata di Daerah Pasal 1 poin 6 yang menyebutkan bahwa "pelaku ekowisata adalah pemerintah, pemerintah daerah, dunia usaha, dan masyarakat yang bergerak di bidang wisata”. Dari Peraturan Menteri Dalam Negeri di atas dapat diketahui bahwa pemerintah dan masyarakat merupakan pelaku 
wisata yang didalamnya memiliki peran penting dalam pengembangan usaha wisata.

Spillane (1991: 133) berpendapat bahwa peran pemerintah dalam mengembangkan pariwisata adalah menyediakan insfrastruktur, memperluas berbagai bentuk fasilitas, kegiatan koordinasi antara aparatur pemerintah dengan pihak swasta, pengaturan dan promosi umum ke luar negeri. Dalam penyediaan insfrastruktur pariwisata pemerintah setempat yakni pemerintah Desa Semen sudah berupaya semaksimal mungkin demi kenyamanan wisatawan seperti perbaikan akses jalan menuju KWE Puspa Jagad. Perbaikan jalan ini tidak hanya dilakukan di kawasan KWE Puspa Jagad, tetapi juga jalur utama menuju KWE Puspa Jagad.

Pemerintah setempat juga menyediakan prasarana air bersih yang dikelola oleh pemerintah yaitu WISLIK, meskipun dalam penggunaannya masyarakat dikenakan tarif akan tetapi penyediaan air bersih ini sangat berguna bagi masyarakat lokal dan wisatawan yang berkunjung di KWE Puspa Jagad. Dalam upaya memperkenalkan KWE Puspa Jagad pemerintah setempat juga melakukan promosi dalam bentuk pameran dan bazar, hal ini bertujuan untuk memperkenalkan potensi yang dimiliki Desa Semen dan juga untuk menarik kunjungan wisatawan.

Masyarakat dalam peranannya sebagai penggerak pariwisata juga merupakan aset yang dimiliki suatu industri wisata, karena ekowisata merupakan pariwisata yang bersifat massal dimana dalam proses pengembangannya melibatkan peran aktif masyarakat, hal ini bertujuan agar masyarakat tidak tersisihkan (keberadaan, budaya, karakteristik ataupun mata pencahariannya), dengan demikian masyarakat dapat merasakan manfaat dari pengembangan ekowisata tersebut.

Suwantoro (2014: 85) bependapat bahwa peran masyarakat dapat dilakukan secara aktif maupun pasif. Peran secara aktif dilaksanakan secara langsung, baik secara perseorangan maupun secara bersama-sama, yang secara langsung berpartisipasi dalam kegiatan pariwisata. Sedangkan peran serta pasif adalah timbulnya kesadaran masyarakat untuk tidak melakukan kegiatan-kegiatan yang dapat mengganggu atau merusak lingkungan alam di sekitar tempat wisata. Keikutsertaan masyarakat tersebut dapat berbentuk pelayanan jasa penginapan. Penyediaan/usaha warung makan dan minuman, penyediaan toko souvenir/ cendera mata, jasa pemandu wisata, fotografi dan menjadi pegawai perusahaan swasta.

Dari temuan peneliti menunjukkan bahwa di KWE Puspa Jagad peran masyarakat dapat dilihat dari berbagai aktivitas seperti adanya jasa penginapan atau homestay meskipun masih menggunakan rumah warga namun fasilitas sudah lengkap meskipun tidak seperti penginapan sekelas hotel. Kemudian penyediaan warung makan dan minuman di lokasi outbond yang disediakan gubuk-gubuk 
permanen oleh pengelola KWE Puspa Jagad. Penyediaan toko souvenir/cendera mata bagi wisatawan yang ingin membeli oleh-oleh khas KWE Puspa Jagad. Untuk jasa pemandu wisata pihak pengelola sudah melakukan sertifikasi guide yang siap memandu wisatawan. Dari semua aktivitas wisata tersebut tujuan utamanya adalah untuk memberdayakan masyarakat sehingga produktivitas dan perekonomian masyarakat meningkat. Meskipun jumlahnya tidak begitu besar namun masyarakat menerima manfaat dari kegiatan pariwisata.

Penerapan Model Community Based Tourism $(C B T)$

Model Community Based Tourism (CBT) yang merupakan strategi perencanaan pengembangan kepariwisataan yang berorientasi pada pemberdayaan masyarakat setempat sebagai subjek pembangunan. Seperti teori yang dikemukakan oleh Sunaryo (2013:140) yang menyatakan bahwa ada tiga prinsip pokok dalam strategi perencanaan pembangunan kepariwisataan dalam konsep CBT yaitu: 1) pengikutsertaan anggotan masyarakat dalam pengambilan keputusan; 2) adanya manfaat yang dirasakan langsung oleh masyarakat lokal dan; 3) pendidikan kepariwisataan pada masyarakat lokal.

1. Pengikutsertaan masyarakat dalam pengambilan keputusan di KWE Puspa Jagad dilakukan dengan mengadakan rapat dan diskusi rutin untuk membahas perkembangan dan permasalahan yang terjadi di KWE Puspa Jagad, rapat rutin ini dilakukan secara periodik oleh pihak pengelola KWE Puspa Jagad yang melibatkan masyarakat setempat, seperti sesepuh desa dan tokoh masyarakat setempat. Pengikutsertaan masyarakat sekitar dalam pengambilan keputusan bukan hanya untuk membahas mengenai permasalahan dan mencari solusi melainkan juga mengetahui tanggapan masyarakat terkait manfaat yang sudah didapat dengan adanya KWE Puspa Jagad, manfaat ini harus benar-benar dirasakan oleh masyarakat sekitar karena suatu industri pariwisata tidak akan dikatakan baik apabila manfaatnya belum dirasakan langsung oleh masyarakat sekitar.

2. Adanya manfaat yang dirasakan oleh masyarakat sekitar. Manfaat yang dirasakan oleh masyarakat sekitar KWE Puspa Jagad antara lain adalah adanya lapangan pekerjaan baru bagi masyarakat, seperti warung-warung di sekitar lokasi wisata dan meningkatnya produktivitas industri gula jawa yang ada di kawasan KWE Puspa Jagad. Dalam hal ini masyarakat yang berada di kawasan KWE Puspa Jagad diberdayakan melalui kegiatan pariwisata. Di KWE Puspa Jagad seluruh akomodasi wisata dilakukan oleh masyarakat, seperti jasa penginapan atau homestay sekitar 15 homestay yang semuanya dikelola oleh masyarakat, 
seperti wisatawan yang menginginkan wisata edukasi pembuatan gula jawa, dari pihak pengelola akan mengarahkan kepada warga yang memiliki industri gula jawa dan langsung mendapat arahan dari pemilik industri gula jawa sedangkan pengelola KWE Puspa Jagad hanya sebagai fasilitator saja, dengan demikian produktivitas mereka akan meningkat.

3. Sedangkan untuk pendidikan kepariwisataan bagi masyarakat setempat telah dilakukan oleh pihak pengelola KWE Puspa Jagad dengan mengadakan perintisan serta percontohan-percontohan kepada masyarakat dengan harapan masyarakat dapat termotivasi dan mempraktikan langsung. Pihak pengelola juga sering melakukan penyuluhan dan sosialisasi kepada masyarakat setempat terkait pengembangan KWE Puspa Jagad sebagai berikut:

Tabel 1. Sosialisasi/Penyuluhan yang sudah dilakukan oleh pengelola Kampung Wisata Ekologis (KWE) Puspa Jagad

\begin{tabular}{|l|l|l|}
\hline No. & \multicolumn{1}{|c|}{$\begin{array}{c}\text { Nama } \\
\text { Kegiatan }\end{array}$} & \multicolumn{1}{|c|}{ Penjelasan/Diskripsi } \\
\hline 1. & $\begin{array}{l}\text { Sosialisasi } \\
\text { menciptakan } \\
\text { rasa aman di } \\
\text { lingkungan } \\
\text { wisata }\end{array}$ & $\begin{array}{l}\text { Penerapan lingkungan yang } \\
\text { nyaman dan aman terutama } \\
\text { bagi pengunjung dan juga } \\
\text { lingkungan masyarakat di } \\
\text { destinasi wisata Setiap } \\
\text { lapisan masyarakat di } \\
\text { destinasi wisata agar ikut } \\
\text { dalam penerapan keamanan } \\
\text { dan kenyamanan. }\end{array}$ \\
\hline 2. & $\begin{array}{l}\text { Peluruh lapisan masyarakat } \\
\text { pembentukan } \\
\text { sikap disiplin dimulai dari kelompok } \\
\text { kerja yang ada mampu } \\
\text { mencerminkan budaya } \\
\text { tertib dan teratur baik } \\
\text { bermasyarakat ataupun saat } \\
\text { ada wisatawan yang }\end{array}$ \\
\hline
\end{tabular}

\begin{tabular}{|c|c|c|}
\hline & & berkunjung. \\
\hline 3. & $\begin{array}{l}\text { Penyuluhan } \\
\text { penerapan } \\
\text { hidup bersih }\end{array}$ & $\begin{array}{l}\text { Penjelasan kepada setiap } \\
\text { pokja agar selalu menjaga } \\
\text { kebersihan lingkungan } \\
\text { masing-masing kelompok } \\
\text { kerja. Memberikan } \\
\text { pengarahan kepada pokja } \\
\text { bank sampah agar sebisa } \\
\text { mungkin mengelola dan } \\
\text { memanfaatkan sampah- } \\
\text { sampah yang ada. }\end{array}$ \\
\hline 4. & $\begin{array}{l}\text { Sosialisasi } \\
\text { penanaman } \\
\text { pohon }\end{array}$ & $\begin{array}{l}\text { Memberikan penjelasan } \\
\text { kepada setiap kelompok } \\
\text { kerja agar di wilayah } \\
\text { destinasi wisata dapat } \\
\text { terlihat sejuk dengan } \\
\text { melaksanakan penghijauan. }\end{array}$ \\
\hline 5 . & $\begin{array}{l}\text { Sosialisasi } \\
\text { penanaman } \\
\text { bunga }\end{array}$ & $\begin{array}{l}\text { Warga di kawasan destinasi } \\
\text { wisata agar menanam bunga } \\
\text { yang terutama di sepanjang } \\
\text { pinggir jalam. Di setiap } \\
\text { kelompok agar membuat } \\
\text { kreativitas tertentu agar di } \\
\text { kelompok kerja tersebut } \\
\text { lebih terlihat indah }\end{array}$ \\
\hline 6. & $\begin{array}{l}\text { Sosialisasi } \\
\text { warga } \\
\text { sebagai guide }\end{array}$ & $\begin{array}{l}\text { Memberikan pengarahan } \\
\text { kepada setiap pelaku wisata } \\
\text { bersikap bersahabat kepada } \\
\text { setiap para pengunjung } \\
\text { yang datang. Menjadi tuan } \\
\text { rumah yang selalu siap } \\
\text { melayani, } \\
\text { informasi, dan memberi } \\
\text { kepada setiap pengunjung } \\
\text { yang datang. }\end{array}$ \\
\hline 7. & $\begin{array}{l}\text { Penyuluhan } \\
\text { kreativitas di } \\
\text { setiap pokja }\end{array}$ & $\begin{array}{l}\text { Membuat kreativitas dan } \\
\text { keunikan yang dapat } \\
\text { ditonjolkan oleh setiap } \\
\text { kelompok kerja yang ada. }\end{array}$ \\
\hline 8. & $\begin{array}{l}\text { Sosialisasi } \\
\text { pengelolaan } \\
\text { Desa Wisata } \\
\end{array}$ & $\begin{array}{l}\text { Ditujukan kepada seluruh } \\
\text { pelaku Kelompok Kerja } \\
\text { KWE Puspa Jagad. }\end{array}$ \\
\hline 9. & $\begin{array}{l}\text { Sosialisasi } \\
\text { PNPM } \\
\text { Pariwisata }\end{array}$ & $\begin{array}{l}\text { Penjelasan pelaksanaan } \\
\text { PNPM Pariwisata }\end{array}$ \\
\hline
\end{tabular}

Sumber: Arsip Pengelola KWE Puspa Jagad.

Tabel 2. Percontohan yang sudah dilakukan Pokdarwis Kampung Wisata Ekologis (KWE) Puspa Jagad kepada masyarakat

\begin{tabular}{|l|l|l|}
\hline No. & \multicolumn{1}{|c|}{$\begin{array}{c}\text { Nama } \\
\text { Kegiatan }\end{array}$} & \multicolumn{1}{|c|}{ Penjelasan / Diskripsi } \\
\hline 1. & $\begin{array}{l}\text { Pemasangan } \\
\text { pot dan } \\
\text { penanaman } \\
\text { bunga chana }\end{array}$ & $\begin{array}{l}\text { Penanaman bunga chana di } \\
\text { sepanjang jalan di destinasi } \\
\text { wisata Agar sepanjang } \\
\text { jalan terlihat sejuk dan } \\
\text { indah. }\end{array}$ \\
\hline 2. & $\begin{array}{l}\text { Pembenahan } \\
\text { dan } \\
\text { pengadaan }\end{array}$ & $\begin{array}{l}\text { Penataan tata ruang sorum } \\
\text { anggrek alam dan membuat } \\
\text { sorum anggrek lebih rapi }\end{array}$ \\
\hline
\end{tabular}




\begin{tabular}{|l|l|l|}
\hline & $\begin{array}{l}\text { Sorum } \\
\text { Anggrek }\end{array}$ & dan kelihatan indah. \\
\hline 3. & $\begin{array}{l}\text { Pengadaan } \\
\text { dan } \\
\text { pembenahan } \\
\text { sarana di } \\
\text { kelompok } \\
\text { kelinci }\end{array}$ & $\begin{array}{l}\text { Penambahan bibit unggul } \\
\text { dan tempat showroom } \\
\text { kelompok kelinci agar lebih } \\
\text { indah. }\end{array}$ \\
\hline 4. & $\begin{array}{l}\text { Pawai ogoh- } \\
\text { ogoh }\end{array}$ & $\begin{array}{l}\text { Dilaksanakan dalam rangka } \\
\text { hari Raya Nyepi yang } \\
\text { diikuti oleh seluruh umat } \\
\text { Hindu dan seluruh warga } \\
\text { KWE }\end{array}$ \\
\hline
\end{tabular}

Tabel 3. Perintisan yang sudah dilakukan oleh Pokdarwis KWE Puspa Jagad kepada masyarakat

\begin{tabular}{|c|c|c|}
\hline No. & $\begin{array}{c}\text { Nama } \\
\text { Kegiatan }\end{array}$ & Penjelasan / Diskripsi \\
\hline 1. & $\begin{array}{l}\text { Pembenahan } \\
\text { jalur air terjun }\end{array}$ & $\begin{array}{l}\text { Membuat jalur-jalur } \\
\text { hacking track untuk } \\
\text { menuju kawasan Air } \\
\text { Terjun Coban Wilis KWE } \\
\text { Puspa Jagad }\end{array}$ \\
\hline 2. & $\begin{array}{l}\text { Pembentukan } \\
\text { Tim SAR } \\
\text { Rescue }\end{array}$ & $\begin{array}{lrr}\text { Dibentuknya } & \text { TIM } & \text { SAR } \\
\text { KWE Puspa } & \text { Jagad } \\
\text { bertujuan } & \text { untuk } \\
\text { memberikan keamanan } \\
\text { dan kenyamanan bagi } \\
\text { pengunjung. }\end{array}$ \\
\hline
\end{tabular}

Sumber: Arsip Pengelola KWE Puspa Jagad.

Penerapan model Community Based

Tourism (CBT) pada pengembangan KWE Puspa Jagad peneliti menyimpulkan bahwa keberhasilan pengembangan potensi wisata di KWE Puspa Jagad adalah pariwisata itu sendiri, karena pada dasarnya keberhasilan CBT sangat mengharapkan adanya partisipasi masyarakat dalam hal perencanaan, penyelenggaraan sampai dengan pemanfaatan hasil industri kepariwisataan yang ada. Dengan penerapan CBT pada pengembangan KWE Puspa Jagad dapat dibilang berhasil, dilihat dari partisipasi, manfaat yang diterima dan kemajuan KWE Puspa Jagad dari awal hingga sekarang.

\section{Pendorong dan Penghambat dalam} Pengembangan Kampung Wisata Ekologis (KWE)

\section{Faktor Pendorong}

Tahap awal dari pembangunan kepariwisataan adalah perencanaan, di dalam tahap ini dalam pembangunan harus melihat berbagai aspek yang berkaitan dengan pariwisata ke depannya. Di setiap pembangunan kepariwisataan tentunya terdapat faktor-faktor yang mempengaruhinya termasuk faktor yang menjadi pendorong sebuah pariwisata, apabila faktor pendorong tersebut dapat dikembangkan dengan baik maka suatu industri pariwisata akan mengalami keberhasilan dalam berbagai hal seperti dalam menarik wisatawan untuk berkunjung. Faktor pendorong pariwisata dapat berasal dari dua faktor yaitu faktor internal dan eksternal.

Menurut pendapat Sunaryo (2013: 64)

faktor pendorong pariwisata yang berasal dari internal seperti:

1. Daya dukung sosial-budaya

Daya dukung sosial-budaya yang unik (lain daripada yang lain) akan memiliki peluang yang lebih besar dalam menarik jumlah wisatawan. Salah satu daya dukung budaya yang dimiliki KWE Puspa Jagad adalah kesenian Langen Beksan dan Jaranan.

2. Daya dukung fisik

Daya dukung fisik merupakan daya dukung lingkungan, baik aspek biotik (Hidup: hewan, tumbuhan, manusia) 
maupun aspek abiotik (Mati: air, udara, suhu, sinar matahari, tanah, dan lainlain). KWE Puspa Jagad memiliki potensi yang cukup besar dalam daya dukung lingkungan. Letak Desa Semen yang strategis yaitu berada di Lereng Gunung Kelud menjadikan kawasan KWE Puspa Jagad memiliki udara yang sangat bersih dan sejuk sehingga wisatawan yang berkunjung merasa nyaman berada di KWE Puspa Jagad ini.

3. Daya dukung ekonomi

Dalam pelaksanaan sebuah pembangunan tentu memerlukan biaya agar seluruh program yang direncanakan berjalan dengan baik dan optimal. Pengembangan KWE Puspa Jagad mendapatkan berbagai macam bantuan terutama bantuan dari Pemerintah dalam bentuk modal, seperti adanya bantuan PNPM Pariwisata, pengembangan KWE Puspa Jagad mendapat perhatian penuh dari pemerintah dalam pengembangan sarana dan prasarana.

4. Daya dukung politik

Daya dukung politik dapat berperan aktif untuk mendorong pengembangan industri kepariwisataan di suatu destinasi. Namun demikian di sisi yang lain, dukungan masyarakat yang rendah bahkan mungkin antagonis, menjadi penghalang besar bagi pengembangan industri kepariwisataan di KWE Puspa Jagad ini.

5. Daya dukung sumber daya lokal
Daya dukung sumber daya lokal bisa berupa tenaga kerja, sumber pendanaan, penyediaan lahan maupun peran aktif pelaku usaha kepariwisataan, dengan ketersediaan sumber daya lokal di KWE Puspa Jagad maka dapat mendukung perkembangan kampung wisata ini dengan memanfaatkan fasilitas yang dimiliki KWE Puspa Jagad tentu dengan dukungan oleh masyarakat sekitar dan pemerintah Desa Semen itu sendiri.

Di samping faktor internal, ada beberapa faktor eksternal yang dapat mempengaruhi daya dukung suatu destinasi pariwisata. Beberapa faktor eksternal tersebut adalah daya dukung insfrastruktur yang menjadi fasilitas pendukung kepariwisataan di KWE Puspa Jagad sebagai berikut:

1. Sarana pariwisata

Sarana pokok pariwisata

Penyediaan sarana pokok pariwisata ini sangat penting untuk memenuhi kebutuhan wisatawan selama berada di daerah tujuan wisata. Untuk itu yang termasuk sarana pokok dari kepariwisataan itu sendiri meliputi hotel, penginapan, atau homestay. Namun saat ini di kawasan KWE Puspa Jagad hanya ada homestay, belum ada hotel ataupun penginapan terdekat yang dibangun. Penyediaan homestay tersebut menjadikan wisatawan asing maupun domestik lebih mudah berbaur dengan masyarakat. Selain itu homestay juga dapat menjadi salah satu sarana yang 
baik untuk pertukaran ilmu pengetahuan yang baik dari luar daerah ke dalam dan sebaliknya. Hingga saat ini sudah ada sekitar 15 homestay yang disediakan oleh pengelola KWE Puspa Jagad, dimana setiap homestay dapat dihuni oleh sekitar empat sampai enam orang pengunjung/wisatawan.

\section{Sarana pelengkap pariwisata}

Sarana pelengkap wisata merupakan fasilitas yang berfungsi melengkapi sarana pokok kepariwisataan. Adapun sarana pelengkap yang sudah dibangun di Kampung Wisata Ekologis (KWE) Puspa Jagad ini adalah pondok kesekretariatan yang berfungsi untuk berkumpulnya pengelola KWE Puspa Jagad dan juga pusat informasi pengunjung apabila ingin melakukan perjalanan wisata ke KWE Puspa Jagad. Penyediaan fasilitas pelengkap ini juga akan terus ditambah sesuai dengan kebutuhan pengunjung, sehingga upaya pengembangan sarana dan prasarana ini juga terus dikembangkan bersama oleh pihak pengelola dan masyarakat setempat.

\section{Sarana penunjang pariwisata}

Sarana penunjang wisata adalah sarana yang diperlukan sebagai sarana pokok dan sarana pelengkap, sarana penunjang yang sudah ada di KWE Puspa Jagad ini adalah pedagang yang berjualan di sekitar area KWE Puspa Jagad. Penyediaan sarana tersebut dilakukan agar pengunjung yang kelelahan setelah aktivitas outbond dapat beristirahat dan membeli makanan ataupun minuman di warung-warung tersebut. Selain itu dari kegiatan ini masyarakat dapat memperoleh tambahan penghasilan dari berjualan di area outbond.

2. Prasarana pariwisata

\section{Prasarana transportasi}

Transportasi mempunyai peranan yang cukup penting bagi suatu daerah tujuan wisata, di samping dapat mengantar wisatawan untuk ke daerah tujuan wisata, transportasi juga menjamin kelancaran aktivitas kehidupan ekonomi. Untuk menuju ke lokasi KWE Puspa Jagad saat ini sudah lumayan memadai, akses menuju ke KWE Puspa Jagad ini dapat dilalui dari dua rute, yaitu dari arah Blitar dan juga dari arah Kota Batu. Namun, kedua akses ini hanya bisa dilewati kendaraan seperti mobil dan truk belum bisa dilewati oleh kendaraan seperti bis, hal ini dikarenakan akses jalan yang tidak luas dan berkelok-kelok selain itu kondisi jalan yang masih berlubang menjadi kendala. Selain itu tidak adanya petunjuk arah menuju KWE Puspa Jagad bagi wisatawan yang berasal dari arah Kota Batu. Ketersediaan akses jalan menjadi hal yang sangat penting 
guna mendukung perkembangan KWE Puspa Jagad ini.

\section{Prasarana komunikasi}

Keberadaan prasarana komunikasi ini sangat diperlukan untuk memberikan kemudahan bagi para pengunjung maupun masyarakat sekitar yang ingin melakukan hubungan komunikasi. Hasil pengamatan peneliti jaringan telekomunikasi di Desa Semen khususnya di area KWE Puspa Jagad sudah relatif baik. Sudah banyak pemancar sinyal telepon yang dibangun di kawasan ini, sehingga komunikasi di area ini sudah dibilang lancar.

\section{Prasarana air dan listrik}

Air bersih di Kampung Wsiata Ekologis (KWE) Puspa Jagad ini diperoleh langsung dari sumur-sumur galian, selain itu dari pemerintah Desa Semen juga membangun fasilitas dalam penyediaan air bersih yang diberi nama WISLIK. Kondisi airnya yang sangat bersih di kawasan KWE Puspa Jagad ini diperoleh dari letak Desa Semen berada di Lereng Gunung Kelud. Kebutuhan air bersih ini dimanfaatkan oleh wisatawan, penduduk sekitar, homestay, dan untuk pokja-pokja KWE Puspa Jagad seperti pokja anggrek, pisang, dan nanas. Sedangkan, untuk sumber daya listrik yang digunakan untuk penerangan sumber daya yang disediakan oleh PLN.
Sumber daya listrik ini sudah mampu menjangkau seluruh kawasan Desa Semen, sehingga untuk masalah listrik sudah bisa dikatakan baik.

\section{Prasarana kesehatan}

Salah satu yang menunjang daerah wisata adalah tersedianya prasarana kesehatan bagi masyarakat sekitar maupun wisatawan. Di kawasan KWE Puspa Jagad ini tersedia satu puskesmas yang berada di pusat desa, selain itu juga ada rumah sakit umum yang berada di Kecamatan Wlingi yaitu sekitar $10 \mathrm{~km}$ dari KWE Puspa Jagad ini. Keberadaan sarana ini sangat diperlukan untuk mengantisipasi adanya gangguan kesehatan yang dialami oleh penduduk sekitar maupun wisatawan yang berkunjung.

\section{Prasarana keamanan}

Untuk mengantisipasi segala bentuk gangguan yang mengancam keamanan objek wisata dan pengunjung, maka diperlukan kerja sama antara pihak pengelola dengan masyarakat setempat. Dalam pembangunan KWE Puspa Jagad sudah dibangun POS pantau di area outbond, pos pantau ini berfungsi untuk menjaga keamanan di lokasi outbond apabila pengunjung melakukan kegiatan di area tersebut, apalagi jika pengunjung melakukan kegiatan pada malam hari, pihak pengelola KWE Puspa Jagad dan 
masyarakat setempat secara bergantian untuk menjaga keamanan di area sekitar secara bergantian untuk menjaga keamanan kegiatan pengunjung KWE Puspa Jagad.

Kampung Wisata Ekologis (KWE)

Puspa Jagad dalam upaya pengembangan untuk menarik kunjungan wisatawan terus melakukan upaya dengan memanfaatkan fasilitas dan ketersediaan sumber daya yang ada. Potensi yang dimiliki KWE Puspa Jagad sudah dikembangkan dengan baik, baik dari pengelola maupun masyarakat setempat.

\section{Faktor Penghambat}

Hambatan yang dialami Kampung Wisata Ekologis (KWE) Puspa Jagad dalam upaya pemberdayaan masyarakat lokal ini dapat datang dari dua faktor yakni faktor internal dan faktor eksternal. Hambatan dari faktor internal yang dialami oleh KWE Puspa Jagad adalah kurangnya sumber daya manusia dan kurangnya lahan-lahan untuk dikembangkan. Sedangkan hambatan yang datang dari eksternal adalah minimnya sarana prasarana yang terdapat di KWE Puspa Jagad.

\section{Faktor Internal}

a) Kurangnya sumber daya manusia untuk mengolah potensi yang dimiliki KWE Puspa Jagad. Berdasarkan temuan peneliti menunjukkan bahwa tingkat pendidikan masyarakat di Desa Semen hanya menyelesaikan pendidikannya sampai tingkat Sekolah Dasar. Begitupun dengan pengelola KWE
Puspa Jagad sendiri yang sebagian besar tingkat pendidikannya adalah Sekolah Menengah Pertama. Hal ini tentu berpengaruh terhadap kinerja organisasi terkait dan juga kualitas SDM serta pola pikir atau mindset dari masyarakat.

b) Kurangnya lahan untuk dikembangkan sebagai objek wisata, hal ini mengakibatkan minimnya Objek Daya Tarik Wisata (ODTW), sebagian besar aset KWE Puspa Jagad merupakan lahan milik pemerintah dan swadaya masyarakat. Seperti lokasi outbond yang merupakan tanah aset milik pemerintah Desa Semen kemudian lokasi sekretariatan yang masih menumpang di salah satu rumah warga yang menjadi pengelola KWE Puspa Jagad.

\section{Faktor Eksternal}

Hambatan yang berasal dari faktor eksternal yang dialami KWE Puspa jagad salah satunya adalah minimnya sarana pokok pariwisata, sarana pelengkap pariwisata, sarana penunjang pariwisata, dan prasarana pariwisata seperti prasarana transportasi, prasarana komunikasi, prasarana air bersih dan listrik, prasarana kesehatan dan prasarana keamanan. Tetapi untuk hambatan yang dialami KWE Puspa Jagad adalah penyediaan prasarana transportasi yang tidak bisa dilewati oleh semua jenis kendaraan hal ini mengakibatkan terhambatnya wisatawan 
yang ingin berkunjung ke KWE Puspa jagad dan pengunjung yang dari rute Kota Batu harus memutar arah yang lebih jauh jika wisatawan menggunakan kendaraan besar seperti Bis. Kemudian prasarana kesehatan, tidak adanya rumah sakit di daerah tersebut, jika sewaktu-waktu terdapat wisatawan yang membutuhkan pertolongan maka akan dibawa ke rumah sakit yang ada di Kecamatan Wlingi yang jaraknya sampai $10 \mathrm{~km}$.

\section{Kesimpulan}

Berdasarkan penelitian yang sudah dilakukan terkait dengan Model Pengembangan Ekowisata dalam Upaya Pemberdayaan Masyarakat Lokal Studi di Kampung Wisata Ekologis (KWE) Puspa Jagad Desa Semen Kecamatan Gandusari Kabupaten Blitar, maka dapat diambil kesimpulan sebagai berikut:

1. Peran pemerintah setempat dalam hal ini adalah pemerintah Desa Semen sudah berupaya untuk meningkatkan pelayanan bagi wisatawan yang berkunjung ke KWE Puspa jagad, seperti perbaikan jalan menuju akses wisata, penyediaan prasarana air bersih, dan juga promosi dalam bentuk bazar dan pameran. Peran masyarakat di kawasan KWE Puspa Jagad sudah baik, hal ini dapat dilihat dari aktivitas yang dilakukan masyarakat di KWE Puspa Jagad seperti penyediaan jasa penginapan atau homestay, penyediaan warung makan dan minuman, dan juga penyediaan souvenir dan cendera mata khas dari KWE Puspa Jagad.

2. Dari hasil penelitian yang sudah dilakukan penulis di lapangan pengembangan Kampung Wisata Ekologis (KWE) Puspa Jagad sudah sesuai dengan prinsip-prinsip dalam model Community Bassed Tourism (CBT) hal ini dapat dilihat dari aktivitas dan kegiatan-kegiatan yang sudah dilakukan oleh pengelola KWE Puspa Jagad.

3. Faktor pendukung yang dimiliki Kampung Wisata Ekologis (KWE) Puspa Jagad adalah adanya daya dukung yang berasal dari faktor internal dan eksternal yang dimiliki KWE Puspa Jagad seperti ketersediaannya insfrastruktur yang dimiliki KWE Puspa Jagad, kemudian faktor penghambat yang dimiliki KWE Puspa Jagad adalah minimnya sumber daya manusia dalam pengelolaan KWE Puspa Jagad.

Berdasarkan pada kesimpulan yang telah dipaparkan, maka saran yang dapat peneliti berikan untuk pengembangan Kampung Wisata Ekologis (KWE) Puspa Jagad dalam upaya pemberdayaan masyarakat lokal adalah:

1. Seluruh stakeholder dari KWE Puspa Jagad agar dapat memahami tugas dan fungsi masing-masing sebagaimana mestinya.

a. Bagi pemerintah daerah yang dalam hal ini pemerintah Kabupaten Blitar agar lebih berkontribusi dalam hal 
penyediaan infrastruktur terkait sarana dan prasarana pariwisata.

b. Bagi pengelola KWE Puspa Jagad agar lebih memperhatikan manajemen pengelolaan organisasi, karena terdapat kelompok kerja (pokja) yang sudah tidak aktif lagi.

c. Bagi masyarakat sekitar KWE Puspa Jagad, khususnya masyarakat Desa Semen agar lebih berperan aktif dalam usaha pengembangan KWE Puspa Jagad karena seluruh kekayaan alam yang dimiliki Desa Semen bukan semata-mata milik KWE Puspa Jagad, akan tetapi milik seluruh masyarakat Desa Semen.

2. Lebih ditingkatkan hubungan yang baik antara pemerintah daerah, desa, pengelola dan juga masyarakat sekitar KWE Puspa Jagad melalui kegiatan sosialisasi, diskusi atau kegiatan lainnya.

\section{Daftar Pustaka}

Andayani, A. A. I., Martono, E., \& Muhamad, M. (2017). Pemberdayaan Masyarakat Melalui Pengembangan Desa Wisata Dan Implikasinya Terhadap Ketahanan Sosial Budaya Wilayah (Studi Di Desa Wisata Penglipuran Bali). Jurnal Ketahanan Nasional, 23(1), 1-16.

Devy, H. A. (2017). Pengembangan Obyek dan Daya Tarik Wisata Alam sebagai Daerah Tujuan Wisata di Kabupaten Karanganyar (Studi Kasus Obyek Wisata Air Terjun Jumog di Kawasan Wisata Desa Berjo Kecamatan Ngargoyoso Kabupaten Karanganyar) (Doctoral dissertation, Universitas Sebelas Maret).

Hudaidah, S., \& Yusup, M. W. (2017). Pemberdayaan Masyarakat Melalui Pengembangan Budidaya Ikan Lele Teknologi Bioflok di Kelurahan Pinang Jaya, Bandar Lampung, Lampung. Jurnal Sakai Sambayan, 1(1), 17-22. Rohim, A. (2013). "Pemberdayaan Masyarakat Melalui Pengembangan Desa Wisata. Skripsi Universitas Islam Negri Sunan Kalijaga Yogyakarta.

Ibad, S. (2017). Kearifan Lokal Pemberdayaan Masyarakat Dalam Pengelolaan Dan Pembangunan Sumberdaya Perikanan Yang Berkelanjutan (Studi Kabupaten Situbondo). Samakia: Jurnal Ilmu Perikanan, 8(1), 24-31.

Lestari Susi. (2010). Pengembangan Desa Wisata Dalam Upaya Pemberdayaan Masyarakat Studi Di Desa Wisata Kembang Arum, Sleman.

Nugroho, I. (2011). Ekowisata dan pembangunan berkelanjutan. Pustaka Pelajar.

Peraturan Dalam Negri Nomor 33 Tahun 2009 tentang Pedoman Pengembangan Ekowisata di Daerah

Pratama, Y. W., \& Wibawa, S. (2015). Strategi Pengembangan Ekowisata Berbasis Masyarakat di Pulau Maratua, Kabupaten Berau, Kalimantan Timur (Doctoral dissertation, Universitas Gadjah Mada).

Saugi, W., \& Sumarno, S. (2015). Pemberdayaan perempuan melalui pelatihan pengolahan bahan pangan lokal. Jurnal Pendidikan dan Pemberdayaan Masyarakat, 2(2), 226-238.

Spillane, J. J. (1987). Pariwisata Indonesia: sejarah dan prospeknya. Kanisius. 
Suwantoro, G. (1997). Dasar-dasar pariwisata. Yogyakarta: Andi Offset.

Sunaryo, B. (2013). Kebijakan pembangunan destinasi pariwisata: konsep dan aplikasinya di Indonesia (No. 1). Penerbit Gava Media Kebijakan Pembangunan Destinasi Pariwisata: Konsep dan Aplikasinya di Indonesia.

Sudana, I. P. (2013). Strategi Pengembangan Desa Wisata Ekologis Di Desa Belimbing, Kecamatan Pupuan Kabupaten Tabanan. Analisis Pariwisata, 13(1), 11-31.

Undang-Undang No. 10 Tahun 2009, Tentang Kepariwisataan, Direktorat Jendral Pariwisata, Jakarta, 2009. 